\title{
The Potential of Butterflies in Tourism Diversification Product: Case Study at Coban Rais Waterfall, Batu, East Java
}

\author{
Agung Sih Kurnianto ${ }^{1 *}$, Imti Yazil Wafa ${ }^{2}$, Faldy Alifianto ${ }^{3}$, Nia Kurniawan ${ }^{4,5}$ \\ ${ }^{1}$ Master Program of Environmental Studies, Graduate Program University of Brawijaya, Malang, Indonesia \\ ${ }^{2}$ Kupu-kupu Indonesia, Malang, Indonesia \\ ${ }^{3}$ Laboratory of Pest and Plant Diseases, Department of Agriculture, University of Brawijaya, Malang, Indonesia \\ ${ }^{4}$ Laboratory of Ecology and Animal Diversity, University of Brawijaya, Malang, Indonesia \\ ${ }^{5}$ Department of Biology, Faculty of Mathematic and Natural Sciences, University of Brawijaya, Malang, Indonesia
}

\begin{abstract}
The diversity of Butterfly in Coban Rais is one of the potential resources for tourism product diversification and development. The aims of this paper are to determine the magnitude of the butterfly potential as a form of tourism products diversification and development in a sustainable tourism industry. There are 107 species of butterfly that come from six families was found in Coban Rais waterfall. Some species have a very large population in a specified activity, such as mud-puddling and mating. Udara akasa has the highest potential to make colony and Cyrestis lutea is a species that have the potential as a major attraction in the mud-puddling activity. Sector 3 , the location of riparian with sand and gravel, is the site of the largest butterfly visits. The dry season is the highlight of a butterfly visit in Coban Rais. Development of human resources is important for the tourism products diversification in Coban Rais, i.e. the butterflies observer and visitors services. We recommend establishing a breeding center for butterfly population recovery and educational goals for visitors.
\end{abstract}

Keywords: butterflies, Coban Rais, product diversification.

\section{INTRODUCTION}

Tourism product has evolved rapidly followed by the rise of profits until early of this decade [1]. The high demand of tourism site reflects the economic development which transform rural areas into cities and urban settlements [2]. However, this development is not well-matched by adequate recreation facilities and people has large of interest on varying destination. This is an opportunity for tourism organizer who immediately undertake massive investments to build and develop attractions, both natural and artificial. Thus many managers, agents, and absorption of labor in the tourism industry lead to a tighter competition [3].

However, in the end, innovation and product diversification will determine the sustainability of a tourism destination. Novelty is mostly sought after by tourists, and many of them would not go again to a place that has been visited [4]. This condition is due to the form of management and development which are not considered by stakeholders. Instead of doing development, many tourism destinations were closed due to no longer visited by tourists, and left the natural

\footnotetext{
* Correspondence address:

Agung Sih Kurnianto

Email : agung.sih.kurnianto@gmail.com

Address : University of Brawijaya, Jl. Veteran Malang, Malang 65145.
}

attraction decay, unemployment, and other ecososial impacts [5].

Ecotourism is nature-based tourism concept which has three main pillars: profits, culture, and recreation [6]. All three became one to build a sustainable tourism and benefit to nature and society. However, ecotourism also have the same challenges and must be faced. Innovation and development is the key to maintain the tourism destination existence through diversification tourism products [7].

Coban Rais is a tourism destination with $70 \mathrm{~m}$ in height waterfall as a main object. It is located in the southwest of Batu: Oro-oro Ombo village, Batu City (Fig. 1), East Java, Indonesia, with an altitude of 1002 meters asl [8]. This location is in the management of PT Perhutani (Persero). Coban Rais is well known by student community and visitors with their fascination in waterfalls. In fact, visitors get to know Coban Rais as a secondary objective on their visit in Batu City [8]. Most of the people do not know any other Coban Rais potential as many species of butterfly habitat. The purpose of this paper is to determine the magnitude of the butterfly potential as a form of diversification on tourism products and plans the future development in sustainable tourism industry. 


\section{MATERIAL AND METHODS}

This research was conducted in three period of observations: dry season (July), monsoons (August-early September), and rainy season (October) 2015. However, every season does not trigger a change in the community structure and their migration. Observations were made only on the type of butterfly that flew during the day (diurnal). Identification used field observation approach. The line between the gatehouses to the waterfall is divided into five main sectors; each sector is $500 \mathrm{~m}$ long (Fig. 2). First sector was cover a parking lots, camp ground, and ticket window, and the last sector was cover waterfall position. Each sector was observed specifically and butterflies as the object identified and documented to support the identification. Several species which requires detail identification on the upper side were catched and their pattern carefully documented. The results of three time observations will be compiled in the form of observation list.

Each location visited by more than 20 individual butterflies was recorded as attractive location [9]. This location indicates that there is temporal abundance (butterfly in colonies) due to mud-puddling or mating behavior. Each location visisted by rare species and rarely were marked as significant locations.

This location could be predicted as habitat of food plant for rare butterflies and require special analysis and attention. Attractive and significant locations were marked in GPS (Global Positioning System) to establish a geographic analysis of data as a support of tourism maps.

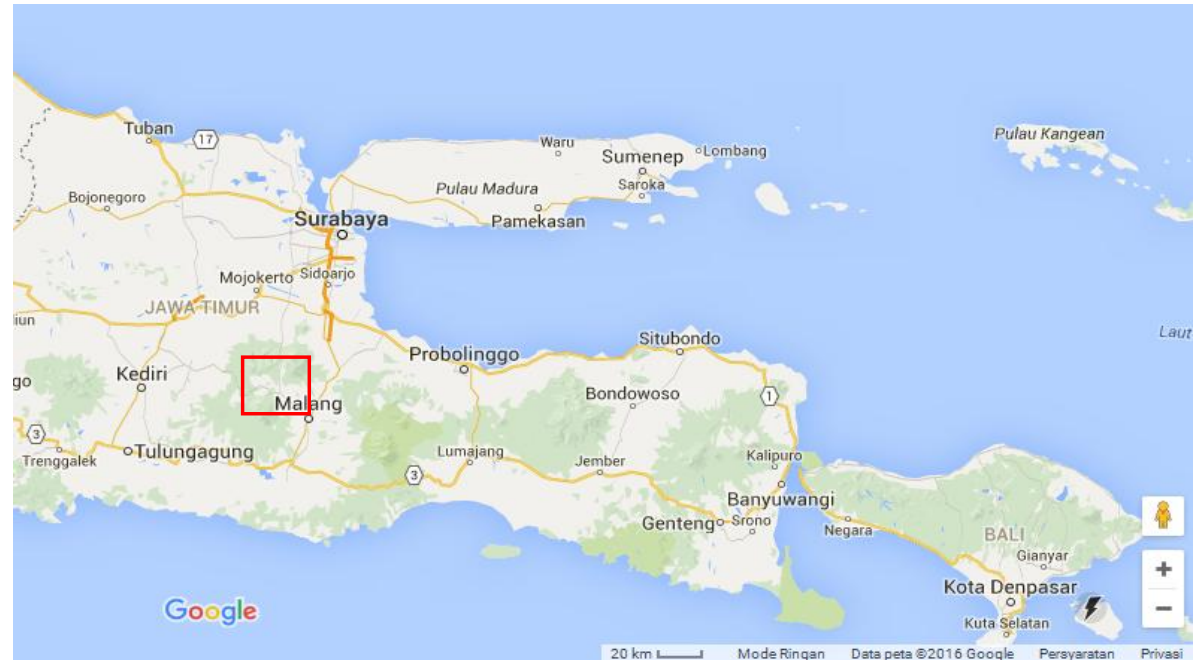

Figure 1. The Location of Coban Rais Waterfall. Description: $\square$ Study Site

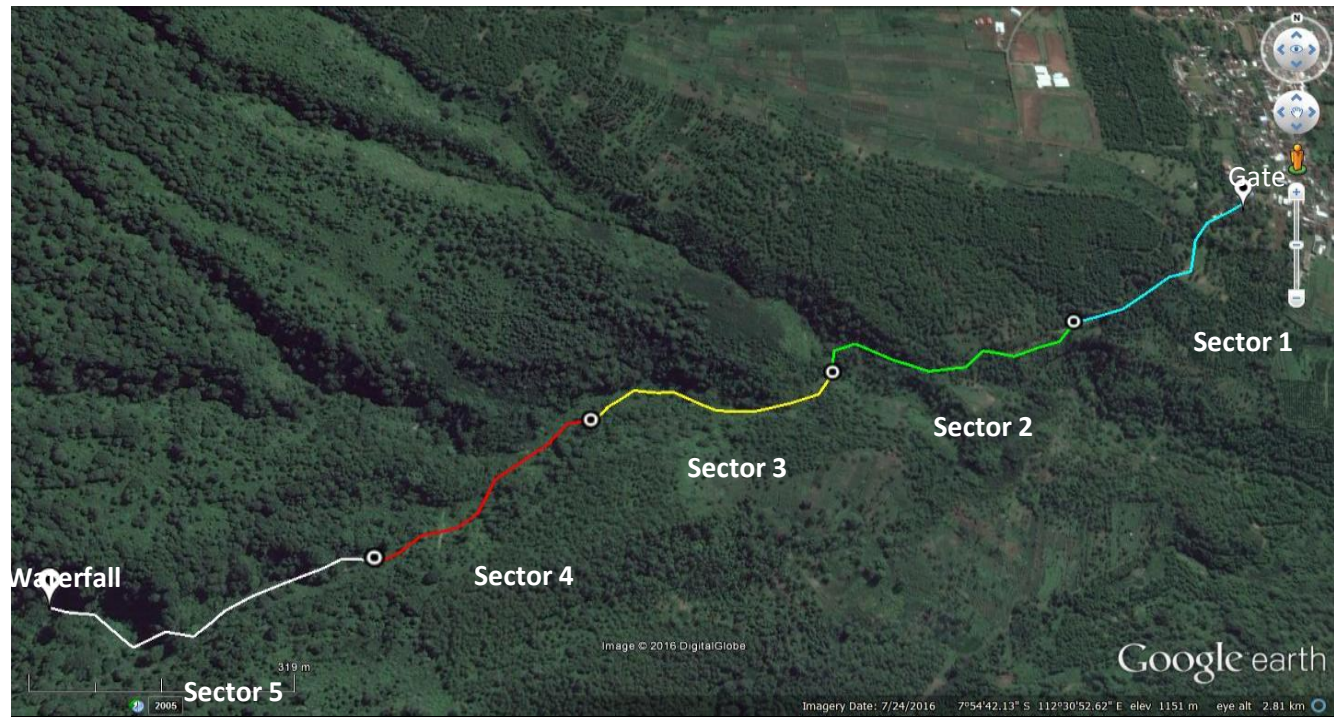

Figure 2. The Waterfall Route that Divided Into 5 Sectors (Source: Google Earth) 
The equipments that used for documenting is 1100 D Canon DSLR camera with kit and a 75-300 $\mathrm{mm}$ USM lens. An insect net with $50 \mathrm{~cm}$ diameter is used to catch butterflies. The results of the observations are recorded as a table form in the field note. Study of literature-based data is done by compiling butterfly-watchers record, either species or families completeness and location.

\section{RESULT AND DISCUSSION}

We discovered 107 species (Appendix 1) that come from six families. Some species have a very large population in a specified activity, such as mud-puddling and mating. We recorded several species that are always found in colonies and solitary. However, some species have the ability to form a large colony than others (Fig. 3), such as Udara akasa Horsfield (Fig.4).

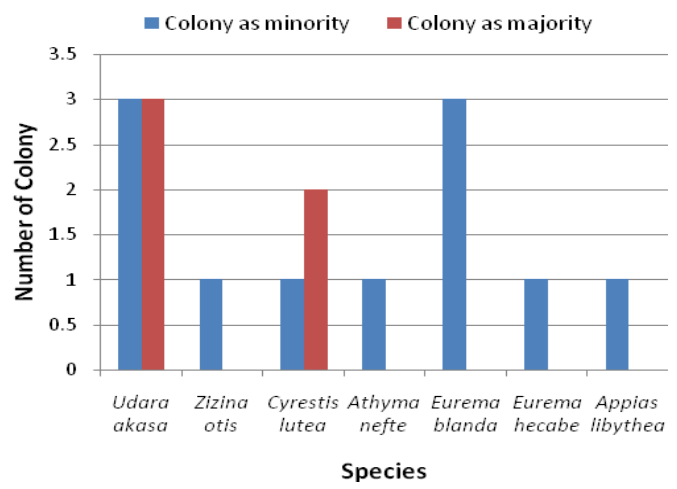

Figure 3. Species Known to Have Ability to Form Colonies

Colony forming process carried out when butterflies do the absorption of minerals together [10]. This activity is more known as mud-puddling. Butterflies absorb minerals such as potassium and sodium which derived from animals and humans sweats, feces, organic waste, or urine [10]. Some minerals dissolved by water and deposited on the wet sand and evaporated, thus attracting butterflies to come and do a mud-puddling activity.

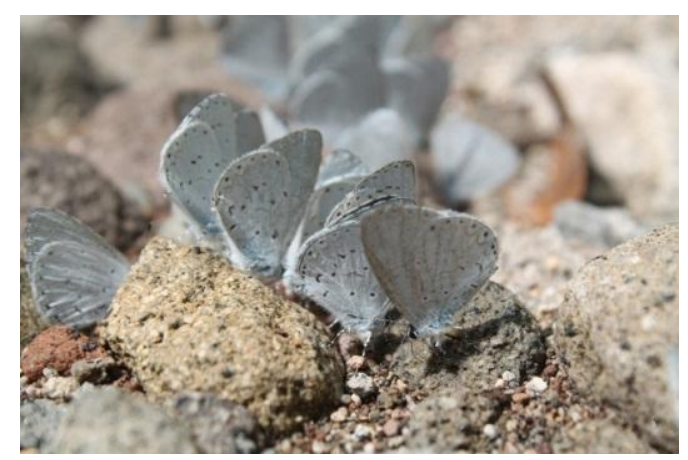

Figure 4. Udara akasa Colony

(Sources : Personal documentation)
We also found a rare species Troides cuneifera Oberthür (Fig. 5) that protected by Indonesian republic government through the UU no.5/1990 [11]. This rare species was found in sector 3 , when its fly through the tourist track.

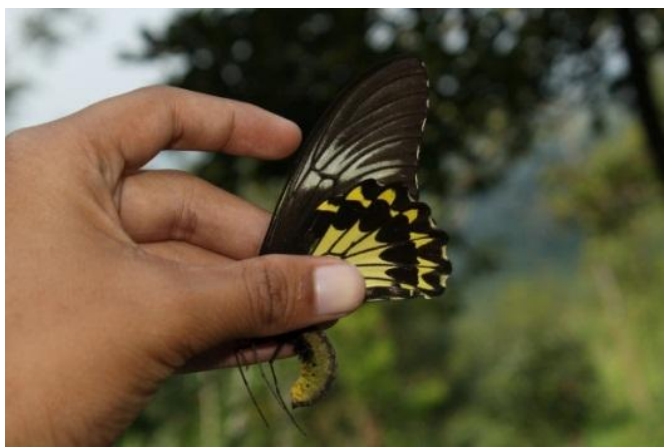

Figure 5.Troides cuneifera

(Sources : Personal documentation)

The observation shows that sector 3 is the most preferred route of butterflies visit, with an average value of 1.75 on three observations time, then followed by sector 1 and sector 4 (Fig. 6). The highest average visit of butterfly in Coban Rais is during the dry season, when many butterflies observed around water flow. During the rainy season which is in the second position, a lot of butterflies seen among the flowers which available along the sector (Fig. 7).

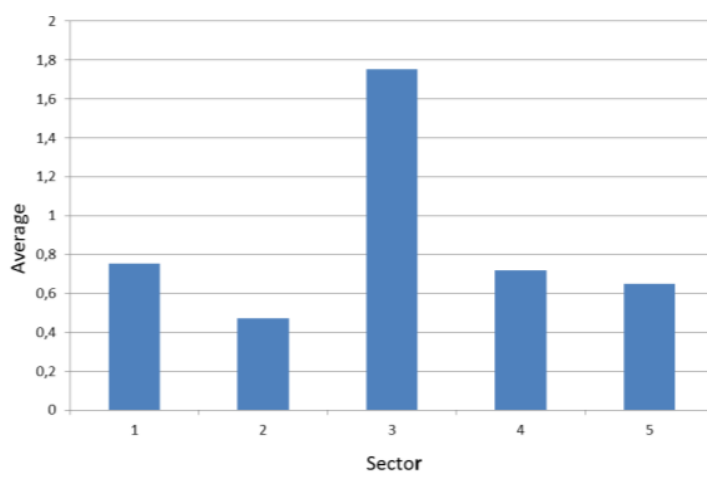

Figure 6. The Average Value of a Butterfly Visit

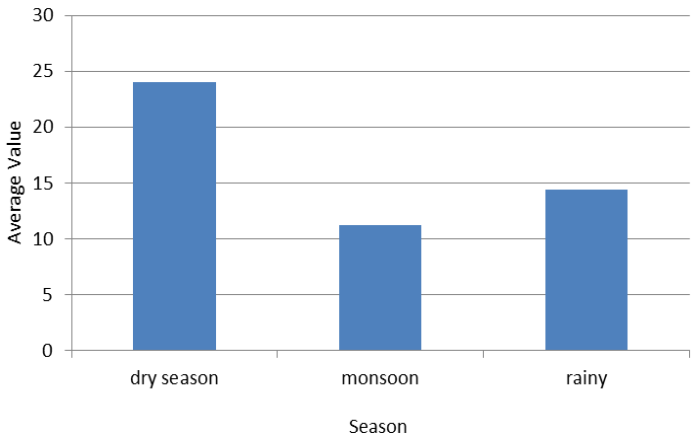

Figure 7. Average Value of Butterfly Visit based on Season 
Coban Rais equipped with water flows which are always there every year. The altitude of 1002 meters makes it into a potential diversity of highlands species that may not exist in other locations. This altitude makes surrounding area of Coban Rais is cool. Besides of the waterfall, the scenery along the route is very interesting (Fig. 8). Visitors can enjoy Batu city scenery from Panderman mountain foothills. Today, many tourist utilize the available facilities, such as camping grounds and jungle trekking route.

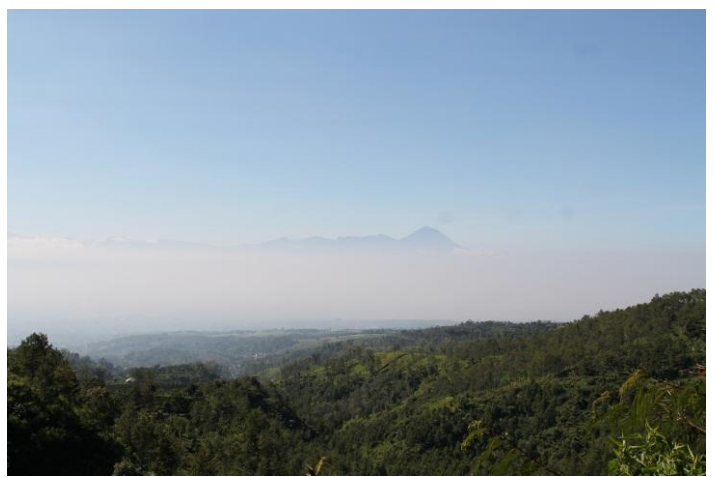

Figure 8. Natural Scenery of the Route to the waterfall (Sources: personal documentation)

Butterflies that found in sector 3 is much higher than in others, even compared to sectors 5 which includes the location of the waterfall. The waterfall is very humid and windy due to the heavy movement of water (Fig. 9), so the less favored by butterflies when they still requires sunlight. Sector 3 is a route that through the stream banks of Coban Rais River. Riparian is often contains of water-borne minerals from organic matter, such as humus, feces, or urine of animals. These deposits evaporate and invite many butterflies to come and do mud-puddling [10].This activity is supported by conditions in sector 3 that has a small plateau and composed by fine sand, gravel and surrounded by a lot of shrubs are available for butterflies as well as a sunbath perch.

Mud-puddling is dominated by Udara akasa (family Lycaneidae). Udara akasa is potential as an interesting object of attraction, because it can be minority part of a colony or dominance in a colony. However, because of the size is very small (1 cm in length), a deep identification is required by arrest or documentation. Udara akasa is not sensitive in human traffic and will soon return to mud-puddling location when disturbed, so make it as interesting side of their attraction. This will make the visitors looks like walk among hundreds of butterflies in that route.

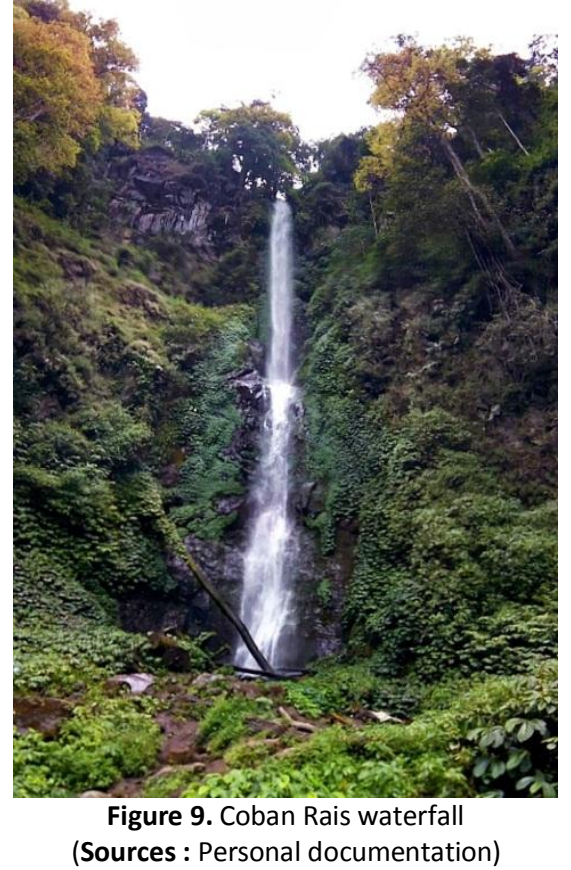

Cyrestis lutea is a butterfly of the Nymphalidae family and became the interesting objects of observations on the mud-puddling activity. In addition to the high ability to form colonies of mud-puddling, this species has a yellow-gold glittered as the sun reflected off. That size is also quite large, so it is very representative when used as an observation object. This is different to Eurema blanda (Pieridae family). This butterfly is in yellow colour that looks very monotonous. It is presence in each colony as minority in a small number.

Sectors 1 and 4 being the location which is pretty much visited by butterflies, supported by large flowering plants found in these locations. Butterflies much need nectar for food. Some butterflies are known to absorb organic material on this site is derived from the sap, rotting fruit, and the fluid that comes out of the shoot. These products contain a lot of sugars that needed by butterflies, especially females [11].

Sector 2 is the route of the least visited by butterflies. Vegetation that seen in sector 2 is short grasses between the pines. The possible reason of the least visit of the butterflies due to plants that are not diverse, thus reducing the potential for the existence of the food chain cycle [12], where the butterfly is included. Observations show that the butterflies were seen in sector 2 just flew through without a perch or any other activities.

Comparison of butterflies in the seasons showed a high butterfly visit during the dry 
season. The scorching sun will make water in soil surfaces and plants evaporated. These conditions favor the evaporation of mineral which contained at top soil, thus supporting the many activities of mud-puddling [13]. In addition, the condition of Coban Rais which always have water is support the activity of mud-puddling, such as mineral dissolution and survival of flower plants.

The lack of rain in time of drought also increases the success of metamorphosis in Lepidoptera, including butterflies [13]. Rainwater will break the cocoon as a part of the metamorphosis.

Rainy season is quite exciting visit a butterfly on a location. Very high rainfall can trigger the growth of flowers and attract butterflies as nectar eaters [14]. Transitional season did not attract butterflies; possibly due to seasonal changes occur often quite extreme. This condition occurs where the rain and heat come in often erratic [15], so that the process of metamorphosis and reproduction of butterflies are often disrupted.

Coban Rais which has the potential of beautiful natural scenery, gifted by a diversity of butterflies that have the potential as a tourism attraction. The emergence of butterflies' colonies on routes strongly supports the ease of visitors to enjoy the butterfly as an object. Visitors can photpgraph the butterflies on the location and the right time. Butterflies in Coban Rais generally can be enjoyed throughout the year, but the knowledge of the right season can help visitors in assessing the condition of the butterflies diversity and time of their visit.

The tourism products such as butterfly or any other wildlife component is a great potential for destination development. In contrast to tourism, major attractions such as scenery or artificial activity, observation of wildlife is not boring and always growing up. Some types of wildlife also have a certain visitors with a selection of tourism concept. This concept applies to the selection and the prices were very strict quotas. Nonetheless, it is still has a visitors enthusiasts [1].

However, in addition to the benefits, the wildlife based tourism has challenges in its development as sustainable industry. The main challenge is to continue the research which provides information that will be used as attractions for visitors. This is related to the appropriate time and location of visits. The strength of wildlife information that intended as an attraction is the main factor in attractions competition or even tourism with the same object.

Research is also crucial to the development of attractions and discovers the limits of carrying capacity [16], in this case is to support the protection of wildlife which became the main object. The condition of the object in the living form is very important to conserved and managed properly, especially developed in: population, the intensity of visits, and the condition of wildlife [1].

Coban Rais in the development of the butterfly as a tourism product requires a few things, especially adequate human resources [17]. The existence of the officer who is specifically understood all wildlife behavior that is used as an object of attraction is very important, especially in the field of behavioral and ecological things. The existence of the officer who is specifically observing the behavior and ecology of the location is very important and contribute any useful information for visitors, after being processed by manager or leader of tourism destination.

Officers within the tourism site needs to develop their ability to serve visitors. Coban Rais is in need officers who served the ticket seller and guiding services in walking through the routes to the waterfall.

Resources in the facilities and infrastructure forms are need to be developed, especially routes that intended specifically as a tourism. Coban Rais has a main route that must be maintained of the carrying capacity for the sustainable butterfly attraction. The cutting of the grass beside of the route should only be done in the rainy season and not done on sector 3 that have a lot of butterflies, to prevent of damaging the food plant or kill the butterfly larvae. It is not recommended to control weeds or wild plants by using chemicals because it will kill all insects, including butterflies.

The attraction infrastucture that support tourism activity has generally been available in Coban Rais, such as parking lots, a ticket window, information boards, directions, bathroom, musholla, camping ground, etc. However, in the development of butterfly as a tourism product, it is advisable to establish a semi-natural breeding center of butterfly. The butterfly observer can breed some species, either rare or not, with the purpose of recovery of butterfly population. In addition, breeding butterflies can be useful to support the benefits of education for visitors such knowledge on the butterflies conservation, 
life cycle, taxonomy, as well as other educational programs [17].

Coban Rais as a nature tourism is very vulnerable to the destruction, such as landslides (Fig. 10), flood, or the collapse of the trees that cover the route. The indispensable treatment of area that will minimize obstruction of route conditions due to damage. The emergency conditions also require immediate repairs and is possible only when managers have officers that ready in restoring routes or other tourist facilities in general.

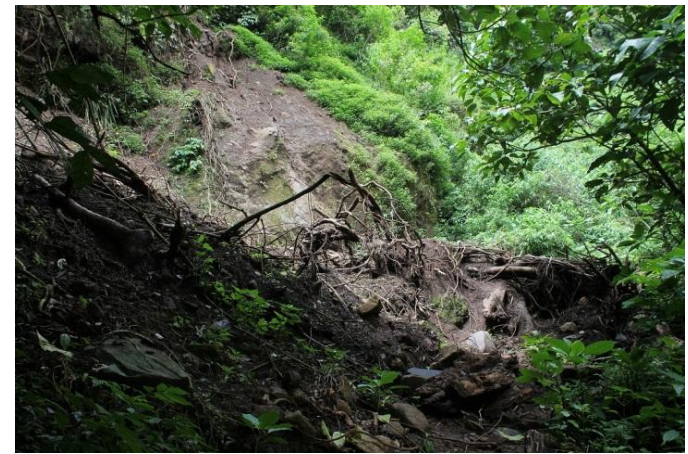

Figure 10. Road damage caused by landslide

\section{CONCLUSION}

The butterflies in Coban Rais was diverse and potentially able to developed as natural attarction. The butterfly development as a tourist attraction in Coban Rais must be supported by human resources, especially knowledge of the field and the ecologicalof butterflies, as well as improve services to visitors. Additional facilities are advised to be built is breeding center as supporting education for visitors and population recovery.

\section{Acknowledgement}

We thank to Perhutani (persero) that supports the butterfly observation process. We are also grateful to Professor Iwan Nugroho that supportsthe writing of this manuscript. We are also thanks to the Laboratory of Ecology and Animal Biodiversity, Departement of Biology, University of Brawijaya and Kupu-kupu Indonesia for the specimens' identification.

\section{REFERENCES}

[1] Isaacs, J. C. 2000. The limited potential of ecotourism to contribute to wildlife conservation. Wildlife Society Buletin 28(1), 61-69.

[2] Smith, S. L. J. 1994. The tourism product. Annals of tourism research. Pergamon Journal 21(3), 582-595.
[3] O'Malley, M. P., K. Lee-Brooks, and H. B. Medd. 2013. The global economic impact of Manta Ray watching tourism. Plos One Journal 8(5), e65051.

[4] Carbone, G. and E. Yunis. 2005. Making tourism more sustainable: a guide for policy maker. United Nations Environment Programme and World Tourism Organization. France.

[5] Neto, F. 2003. A new approach to sustainable tourism development : moving beyond environtmental protection. Desa Discussion Paper 29.

[6] Pforr, C. 2001. Concepts of sustainable development, sustainable tourism, and ecotourism: defintions, principles, and linkages. Scandinavian Journal of Hospitality and Tourism 1(1), 68-71.

[7] Benur, A. M. and B. Bramwell. 2015. Tourism product development and product diversification in destinations. Journal of Tourism Management 50, 213-224.

[8] Nurhidayanti, S. E. 2009. Sistem pariwisata di Agropolitan di Batu. Jurnal Media Masyarakat, kebudayaan, dan Politik 22(1), 76-85.

[9] Sreekumar, P. G. and M. Balakrishnani. 2001. Habitat and altitude preferences of butterflies in Aralam Wildlife Sanctuary, Kerala. Journal of Tropical Ecology 42(2), 277281.

[10] Inoue, T. A., T. Ito, H. Hagiya, T. Hata, K. Asaoka, F. Yokohari, and K. Niihara. 2015. $\mathrm{K}^{+}$ excretion: The other purpose for puddling behavior in Japanese Papilio Butterflies. Plos One Journals 10(5), e0126632.

[11] Government Regulation. 1997. No. 7: preservation of flora and fauna species. Ministry of Nation Secretary. Jakarta.

[12] Bauerfeind, S. S., K. Fischer, S. Hartstein, S. Janowitz, and D. Martin-Creuzburg. 2007. Effects of adult nutrition on female reproduction in a fruit-feeding butterfly: The role of fruit decay and dietary lipids. Journal of Insect Physiology 53(9), 964-973.

[13] Deyn, G. B., C. E. Raaijmakers, J. van Ruijven, and W. H. van der Putten. 2004. Plant species identity and diversity effects on different trophic levels of nematodes in the soil food web. OIKOS Journal 106(3), 576-586.

[14] Emmel, T.C. and C. F. Leck. 1970. Seasonal changes in organization of tropical rain forest butterfly populations in Panama. Journal of research on the Lepidotera 8(4), 133-152. 
[15] Beaumont, L. J. and L. Hughes. 2002. Potential changes in the distributions of latitudinally restricted Australian butterfly species in response to climate change. Global Change Energy Journal 8(10), 954-971.

[16] Xinjun, L. J. Y. 1999. Research on sutainable tourism development and planning in ecotourism destinations. Journal of Natural Resources 1, 79-83.

[17] Baum, T. 2007. Human resources in tourism: Still waiting for change. Journal of Torism management 28(6), 204-212.

Appendix 1. Table of Species Record

\begin{tabular}{|c|c|c|}
\hline No & Species & Family/Subfamily \\
\hline 1 & Ampittia dioscorides & Hesperiidae \\
\hline 2 & Bibasis sena & Hesperiidae \\
\hline 3 & Bibasis oedipodea & Hesperiidae \\
\hline 4 & Borbo cinnara & Hesperiidae \\
\hline 5 & Halpe sikkima & Hesperiidae \\
\hline 6 & Notocrypta paralysos & Hesperiidae \\
\hline 7 & Oriens gola & Hesperiidae \\
\hline 8 & Parnara apostata & Hesperiidae \\
\hline 9 & Pelopidas conjucta & Hesperiidae \\
\hline 10 & Polytremis lubricans & Hesperiidae \\
\hline 11 & Potanthus omaha & Hesperiidae \\
\hline 12 & Potanthus trachala & Hesperiidae \\
\hline 13 & Potanthus ganda & Hesperiidae \\
\hline 14 & Pseudocoladenia dan & Hesperiidae \\
\hline 15 & Tagiades japetus & Hesperiidae \\
\hline 16 & Tagiades gana & Hesperiidae \\
\hline 17 & Taractrocera archias & Hesperiidae \\
\hline 18 & Telicota colon & Hesperiidae \\
\hline 19 & Telicota ohara & Hesperiidae \\
\hline 20 & Udaspes folus & Hesperiidae \\
\hline 21 & Arhopala sp. & Lycaenidae \\
\hline 22 & Arhopala sp. & Lycaenidae \\
\hline 23 & Arhopala eumophus & Lycaenidae \\
\hline 24 & Catochrysops strabo & Lycaenidae \\
\hline 25 & Heliophorus epicles & Lycaenidae \\
\hline 26 & Jamides alecto & Lycaenidae \\
\hline 27 & Lampides boeticus & Lycaenidae \\
\hline 28 & Leptotes plinius & Lycaenidae \\
\hline 29 & Miletus boisduvalli & Lycaenidae \\
\hline 30 & Miletus symethus & Lycaenidae \\
\hline 31 & Nacaduba berenice & Lycaenidae \\
\hline 32 & Poritia erycinoides & Lycaenidae \\
\hline 33 & Prosotas dubiosa & Lycaenidae \\
\hline 34 & Prosotas nora & Lycaenidae \\
\hline 35 & Udara akasa & Lycaenidae \\
\hline 36 & Zameros flegyas & Lycaenidae \\
\hline 37 & Zizina otis & Lycaenidae \\
\hline 38 & Euripus nyctelius & Nymphalidae - Apaturinae \\
\hline 39 & Hestina mimetica & Nymphalidae - Apaturinae \\
\hline 40 & Acraea issoria & Nymphalidae - Apaturinae \\
\hline 41 & Ariadne ariadne & Nymphalidae - Biblidinae \\
\hline 42 & Cyrestis lutea lutea & Nymphalidae - Cyrestinae \\
\hline 43 & Euploea eyndhovii & Nymphalidae - Danainae \\
\hline 44 & Argynnis hyperbius & Nymphalidae - Heliconiinae \\
\hline 45 & Vagrans egista & Nymphalidae - Heliconiinae \\
\hline 46 & Athyma nefte & Nymphalidae - Limenitidinae \\
\hline 47 & Discophora sondaica & Nymphalidae - Limenitidinae \\
\hline 48 & Euthalia aconthea & Nymphalidae - Limenitidinae \\
\hline 49 & Euthalia monina salia & Nymphalidae - Limenitidinae \\
\hline 50 & Euthalia whiteheadi & Nymphalidae - Limenitidinae \\
\hline 51 & Neptis hylas & Nymphalidae - Limenitidinae \\
\hline 52 & Phaedyma columella & Nymphalidae - Limenitidinae \\
\hline
\end{tabular}




\begin{tabular}{|c|c|c|}
\hline No & Species & Family/Subfamily \\
\hline 53 & Hypolimnas anomala & Nymphalidae - Nymphalinae \\
\hline 54 & Hypolimnas bolina (Female record) & Nymphalidae - Nymphalinae \\
\hline 55 & Ideopsis gaura & Nymphalidae - Nymphalinae \\
\hline 56 & Junonia iphita & Nymphalidae - Nymphalinae \\
\hline 57 & Symbrenthia anna & Nymphalidae - Nymphalinae \\
\hline 58 & Symbrenthia hypselis redonsilla & Nymphalidae - Nymphalinae \\
\hline 59 & Symbrenthia lilaea & Nymphalidae - Nymphalinae \\
\hline 60 & Elymnias casiphone & Nymphalidae - Satyrinae \\
\hline 61 & Elymnias hypermnestra & Nymphalidae - Satyrinae \\
\hline 62 & Elymnias nesaea & Nymphalidae - Satyrinae \\
\hline 63 & Lethe confusa & Nymphalidae - Satyrinae \\
\hline 64 & Lethe minerva & Nymphalidae - Satyrinae \\
\hline 65 & Melanitis leda & Nymphalidae - Satyrinae \\
\hline 66 & Mycalesis fuscum & Nymphalidae - Satyrinae \\
\hline 67 & Mycalesis horsfieldi & Nymphalidae - Satyrinae \\
\hline 68 & Mycalesis perseus & Nymphalidae - Satyrinae \\
\hline 69 & Mycalesis sudra & Nymphalidae - Satyrinae \\
\hline 70 & Neptis hylas & Nymphalidae - Satyrinae \\
\hline 71 & Neptis vikasi & Nymphalidae - Satyrinae \\
\hline 72 & Orsotriaena medus & Nymphalidae - Satyrinae \\
\hline 73 & Parantica albata & Nymphalidae - Satyrinae \\
\hline 74 & Tanaecia palguna & Nymphalidae - Satyrinae \\
\hline 75 & Ypthima pandocus & Nymphalidae - Satyrinae \\
\hline 76 & Ypthima philomela & Nymphalidae - Satyrinae \\
\hline 77 & Ypthima baldus & Nymphalidae - Satyrinae \\
\hline 78 & Ypthima nigricans & Nymphalidae - Satyrinae \\
\hline 79 & Ypthima pandocus & Nymphalidae - Satyrinae \\
\hline 80 & Ypthima philomela & Nymphalidae - Satyrinae \\
\hline 81 & Papilio helenus & Papilionidae - Papilioninae \\
\hline 82 & Papilio memnon memnon (Female record) & Papilionidae - Papilioninae \\
\hline 83 & Troides cuneifera cuneifera (Female record) & Papilionidae - Papilioninae \\
\hline 84 & Papilio paris & Papilionidae - Papilioninae \\
\hline 85 & Papilio polytes & Papilionidae - Papilioninae \\
\hline 86 & Troides helena & Papilionidae - Papilioninae \\
\hline 87 & Catopsilia pomona & Pieridae - Coliadinae \\
\hline 88 & Catopsilia scylla & Pieridae - Coliadinae \\
\hline 89 & Eurema andersonii & Pieridae - Coliadinae \\
\hline 90 & Eurema beatrix & Pieridae - Coliadinae \\
\hline 91 & Eurema blanda & Pieridae - Coliadinae \\
\hline 92 & Eurema brigitta & Pieridae - Coliadinae \\
\hline 93 & Eurema hecabe & Pieridae - Coliadinae \\
\hline 94 & Eurema lacteola & Pieridae - Coliadinae \\
\hline 95 & Eurema tilaha & Pieridae - Coliadinae \\
\hline 96 & Appias libythea & Pieridae - Pierinae \\
\hline 97 & Appias pandione & Pieridae - Pierinae \\
\hline 98 & Cepora iudith & Pieridae - Pierinae \\
\hline 99 & Delias belisama (Female record) & Pieridae - Pierinae \\
\hline 100 & Delias pasithoe & Pieridae - Pierinae \\
\hline 101 & Delias aurantia & Pieridae - Pierinae \\
\hline 102 & Gandaca harina & Pieridae - Pierinae \\
\hline 103 & Hebomoia glaucippe & Pieridae - Pierinae \\
\hline 104 & Leptosia nina & Pieridae - Pierinae \\
\hline 105 & Prioneris autothisbe & Pieridae - Pierinae \\
\hline 106 & Prioneris autothisbe & Pieridae - Pierinae \\
\hline 107 & Zemeros flegyas & Riodinidae \\
\hline
\end{tabular}

